\title{
Influence of School Workplace Condition on Teachers' Job Satisfaction in Public Secondary Schools in Bukoba Rural District in Kagera Region, Tanzania
}

\author{
Jenipher Modest, Daniel O. Onyango
}

Department of Educational Foundation, St. Augustine University of Tanzania, Tanzania

Received: 11 Sep 2021; Received in revised form: 18 Oct 2021; Accepted: 25 Oct 2021; Available online: 31 Oct 2021

(C)2021 The Author(s). Published by Infogain Publication. This is an open access article under the CC BY license (https://creativecommons.org/licenses/by/4.0/).

\begin{abstract}
This study sought to examine the influence of school workplace condition on teachers' job satisfaction in public secondary schools in Bukoba Rural District. It was guided by three research objectives namely: To find out teachers perceptions about the workplace standards to teacher's job satisfaction in public secondary schools, to determine the contribution of school workplace standards on teachers' job satisfaction in public secondary schools and the third objective was to identify strategies which can be adopted to improveworkplace standards so as to enhance teachers' job satisfaction. The study employed a mixed research approach and convergent parallel research design. A total sample size of 100 participants was involved in the study. The participants were sampled through simple random and purposive sampling techniques. Questionnaires and interviews were employed as the methods of data collection. Validity of research instruments was ensured by exposing them to the supervisor and panellists for analysis while questionnaires have a Cronbach's Alpha correlation coefficient of 0.76 which means the instruments were reliable. Both quantitative and qualitative data were collected and analyzed through descriptive statistics and thematic analysis respectively. The study found that poor workplace condition is experienced in the visited schools and therefore there is low level of job satisfaction among teachers in the visited schools. The results further reveal that poor workplace standards that are characterized with grievances among teachers, hostility among teachers, teachers living away from their spouse, poor relationship between teacher and supervisor, inadequate teacher housing and teachers health safety were reported to have the potential influence so that teachers can work in a healthy manner and hence their level of job satisfaction can increase. The study recommends that there should be effective and efficient policy framework that can motivate education stakeholders to participate in improving school workplace condition for teachers to work harmoniously and therefore may have high level of job satisfaction.
\end{abstract}

Keywords - School Workplace, Public Secondary Schools, Job Satisfaction, Rural District.

I.

INTRODUCTION AND BACKGROUND OF THE STUDY

Workplace conditions raised following industrial revolution in the year 1950. The industrial revolution was accompanied with the introduction of white color jobs. This was because Industrial revolution in Europe was involved by inventions of various machines which replaced human (Shibitali, 2012). Allodi and Fischbein
(2012) conducted a study in Sweden on teachers' perceptions of working conditions for more than 700 Swedish junior high school teachers from 32 schools. Results showed that women were less satisfied with their teaching workload, and that younger teachers perceived having less professional autonomy than their more experienced colleagues.Teachers in English schools are also more likely to want to move school than teachers in other English speaking participating countries, though the 
difference is not statistically significant (Sims,2017). In the international context, Sims $(2017,2018)$ analyzed teacher data in 35 countries worldwide from Teaching and Learning International Survey (TALIS) 2013 - an international study of school learning environments and working conditions. It was found that student discipline and teacher cooperation were positively related to teacher job satisfaction in all countries.. Alyaha and Mbogo(2017) Country submit that there has been increased number of transfer requests to the county director of education and teachers quitting the teaching profession. This could be an indicator that teachers are not satisfied with the situation of their working environment. Workers are satisfied when the work place is orderly with adequate tools, materials and a favorable environment while poor equipment and facilities may lead to tension and stress among employees. In Tanzania, and Africa in general official works can be traced back to the time of colonialism in(1973). The introduction of colonialism in Africa by white people was accompanied by colonial education. Colonial education was given to few Africans especially the sons and daughters of chiefs to save the colonial government. Putting in consideration that, human being is not like a machine, he requires good workplace conditions to produce best results. Workers associations in Tanzania was adopted from that of Europe in the year 1973 with the same intentions, that is, to demand workers' rights including good working conditions, fair payment, all of which enable workers to accrue expected results.According to Msuya (2016) job satisfaction is a crucial element in maintaining quality human resources and life of any organization, in school job satisfaction is among the cornerstones for the improved students' performance. However, a recent review of the literature suggests that working conditions in schools may be a more important reason for high turnover (Simon \& Johnson, 2015).

In Tanzania studies has been conducted on the topic of teachers' job satisfaction. Msuya (2016) reviewed that for teachers to satisfy with their job, teacher needs the presence of job security, possibility for academic growth, employee relation and good working condition. Therefore studies of Ntagahali (2016), William (2016) and Evarist (2013) shows that in Tanzania, there is strong evidence showing that the majority of teachers are unhappy with their teaching situation. It is against this background that this study attempts to assess the influence of workplace condition on teachers' job satisfaction specifically basing on workplace standards in public secondary schools in Bukoba Rural District in Kagera Region, Tanzania.

\section{Statement of the Problem}

Tracing back in seventh workers were treated as machinery, it was against this situation they had to form workers associations so that they could fight for their right. It is said that, teachers' salary, promotion, supervision, recognition and working condition are the most important factors that influence teachers' job satisfaction. Nyange (2013) Unfortunately, in many public secondary schools in Bukoba Rural District even teachers themselves alleged that there were growing cases of poor workplace standards such as living far from ones' spouse, lack of accommodation, poor employees and supervisors' relation, teachers' grievance, poor health safety all of which affects teachers job satisfaction. This study therefore intended to find out the truth about those allegations and how they affect teachers' job satisfaction in public secondary schools in Bukoba Rural District. According to Ntagahali(2016) Teachers' job satisfaction is affected by various factors including poor working condition such as presence of hostility between teachers and supervisors and among teachers themselves, poor living conditions like acute shortage of teachers' accommodation together with low salaries. Ntagahali (2016) adds that teachers' working environment do not invite teachers to work specifically in remote areas compared to the urban areas. Nevertheless, Ntagahali (2016) study left out the allegations like living far from spouses, teachers health safety, and grievances among teachers. This study therefore intended to bridge this gap by targeting the influence of living together with spouse, presence of teachers' health safety particularly during COVID 19, presence of accommodation, teachers' good relation to the teachers' job satisfaction specifically in Public Secondary schools in Bukoba Rural District.

\section{Objectives of the study}

The purpose of this study was to assess the influence of school workplace conditions on teachers' job satisfaction in public secondary schools in Bukoba Rural District.This study was guided by the following specific objectives;

i. To find out teachers perceptions about the workplace standards to teachers' job satisfaction in public secondary schools in Bukoba Rural District.

ii. To determine the contribution of workplace standards on teachers' job satisfaction in public secondary schools in Bukoba Rural District.

iii. To identify strategies that can be adopted to improve workplace standard so as to enhance sustainable teachers' job satisfaction.

5 Research Questions

This study was guided by the following research questions. 
Public Secondary Schools in Bukoba Rural District in Kagera Region, Tanzania

i. What are the teachers 'perceptions about workplace standards in secondary schools in Bukoba?

ii. In what ways do workplace standards contribute to teachers' job satisfaction?

iii. What strategies can be adopted to enhance sustainable teachers' job satisfaction in public secondary schools in Bukoba Rural District?

\section{Significance of the Study}

This study intended to investigate workplace condition and its contribution to teachers' job satisfaction in public secondary schools in BukobaRural District. Thus, the findings of study may inform policymakers to develop policies that can contribute to the improvement of workplace condition to be standard in such a way may enhance job satisfaction among teachers. The findings of this study also has the potential of helping the government of Tanzania through the Ministry of Education, Science,

Dependent variable

\begin{tabular}{|l|}
\hline Working Environment \\
- Grievances among teachers \\
- Living away with spouses \\
- Teachers accommodation \\
- Employee and supervisors' \\
- relation \\
- Hostility among teachers \\
Teachers health safety \\
\end{tabular}

Source: Researcher's own construct (2020)

The conceptual framework (Figure 1.1 above shows that there is a relationship between school workplace condition and teachers' job satisfaction. Therefore, availability and suitability grievances among teachers, living away from spouses, the employee and supervisors' relation teachers accommodation, hostility among teachers and health safetymay contribute to high or low level of job satisfaction among teachers. Nevertheless, the relationship
Technology and Vocational Training (MeSTVT) to realize the potential of improve workplace standard for teachers and take the necessary actions like a reasonable way of preventing Grievance among teachers in workplace, a suitable way for spouses to live together instead of living away from each other, good employees and supervisors' relation, adequate accommodation, absences of hostility among teachers and the operational facilities enough that will help to fight against ovoid 19.

\section{Conceptual Framework}

The conceptual framework is defined as the interlinking concept that together provides a comprehensive understanding of a phenomenon (Jabareen, 2009). It is a system of explaining a phenomenon by specifying the variables and the laws that relate the variables to each other (Oso\&Onen). Therefore, the purpose of conceptual framework is to help to quickly understand the relationship between variables. Thus, this study was guided by the following conceptual framework.Figure 1.1 Conceptual framework

independent variable

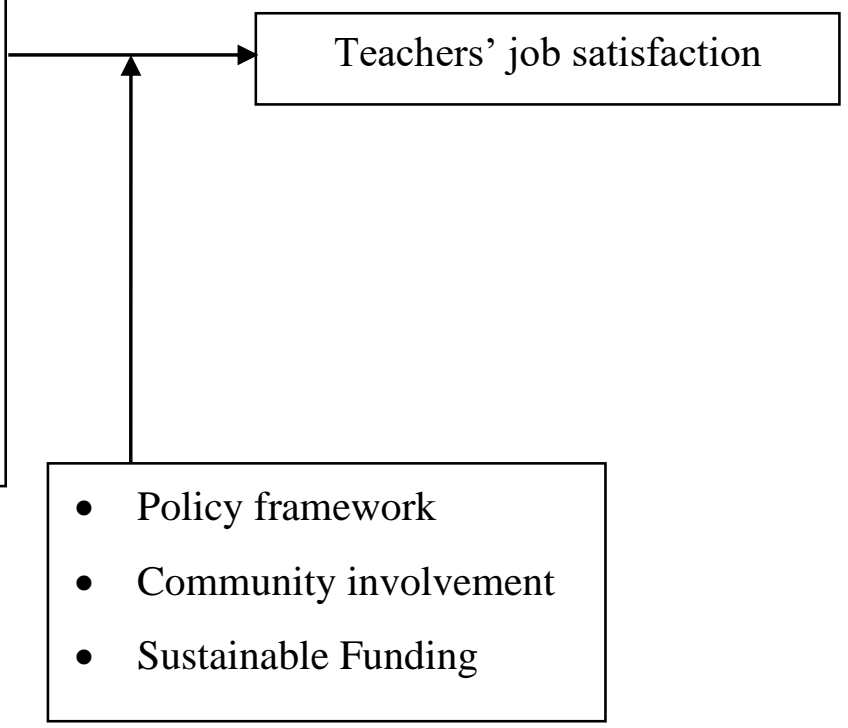

between workplace condition and teachers' job satisfaction can be enhanced by the use and implementation of effective policies, reliable funds and effective community involvement can help to improve the workplace condition through which the level of job satisfaction among teachers can be improved. The presence of un-implementable policies, poor community involvement and unreliable sources of funds lower the effect of the independent 
variables on the dependent variable which may have a detriment effect on teachers' job satisfaction.

\section{LITERATURE REVIEW}

\section{Theoretical Literature Review}

This study was modeled on the theory ofgeneral systems theory (GST) propounded by Von Bertelanffy in 1956 in which he presents the general system theory as a complex of interacting elements (Meles, Pels\&Polese, 2010). A general systems theory is hence a theoretical perspective that analyzes a phenomenon seen as a whole and not as simply the sum of elementary parts. (Meles, Pels\&Polese, 2010). (McShane\& von Glinow, 2003 cited in Chikere\&Nwoka, 2015).This study adopted general systems theory because it provides perspectives and concepts in developing modern school environment (Germain, 2015). The system enhances the development of functionalism, interpretive and adaptive school environment (Porter \& Cordoba, 2010) in which teachers and students can interact effectively with the school resources during the implementation of both curricular and extracurricular activities.

\section{Empirical Literature Review}

\section{Teachers perceptions about work place standards}

Teachers believe that if there could be a chance for suitable way of settling grievances and hostility among teachers, spouse to live together, a good relation between teacher and supervisor, teachers accommodation in school area they are likely to be the contributor for their job satisfaction. In relation to that Patrick (2007) in the study conducted in Statesboro, Georgia on examination of teacher workplace satisfaction and students' achievements viewed that when a teacher's perception of the school culture was supportive, teachers were more likely to feel positively toward their workplace and motivated to provide quality in their job performance. However, individual responses to the work environment were based, to a large extent, upon the individual's expectations.. Astudy of 110 teachers in Abbottabad, Pakistan, by Naseem and Salman (as cited in Okeke\&Mtyuda, ( 2017) suggests that factors such as gender, education, marital status, relationship with the supervisor/principal and co-workers as well as sense of job security are correlates of either satisfactionor dissatisfaction among the participants.

Hosseinkhanzadeh, Hosseinkhanzadeh and Yeganeh (2013) investigated on the relationship between job satisfaction and organizational culture among teachers in Iran. The study employed quantitative research approach. The findings showed that most of the components of school culture including leadership and management support have a positive relationship with teacher job satisfaction. In other words, visionary school leadership can develop strategies that can help to address some teachers' grievances which in turn can boost their level of job satisfaction.

\section{The contribution of workplace standards on teachers job satisfaction}

The aspects of workplace standard considered in this study include but not limited to grievances among teachers, living away with spouse, teacher and supervisors' relation, teachers' accommodation, hostility among teachers and health safety to teachers specifically on war against corona virus(covid19)

\section{Grievances among teachers}

Issues of grievance are normally associated with dissatisfaction among employees which relate to working procedure, working facilities! Bean (1994) confusions on provisions stated on company's policy (Ayaaurai, 1990) and the violations of provisions in terms and conditions of employment stated in collective agreement (Salomon, 2000). In resolving grievances, aggrieved employees will file their dissatisfaction through grievance procedure and their immediate managers or supervisors are responsible to take action within a given period (Rose, 2004). Appropriate styles used to resolve workers' grievance will improve the efficiency and effectiveness of grievance procedure (Rahim, Magner\& Shapiro, 2000). Rahim's OrganizationalConflict Inventory -II (ROCI-II) has identified styles of handling grievances. The instrument combines two dimensions, that is, concern of self and concern of others (Rahim \&Magner, 1995). Combining these dimensions, they have introduced five styles of grievance handling namely avoiding, dominating, obliging, compromising and integrating. Gomez (2005) states that managers therefore need special training on how they should apply the styles and the Human Resource department should provide guidance wherever necessary.

Constructive grievance handling largely depends on ability of managers and supervisors to recognize, diagnose, and correct the causes of potential employee dissatisfaction before they become formal grievances (Chaykowski\&Slotsve, 1992; Tan, 1994). Ivancevich (2001) mentioned that supervisors should take every grievance seriously, work with the union representative, gather all information available on the grievance, after weighing all the facts, provide an answer to the employee who is voicing the grievance. Hook et al(1996) conducted a study on supervisor and manager styles in handling grievances. The study utilized styles established by Wright and Tayior which are "tell", "tell and sell", "tell and listen", "ask and tell", "problem solving" and "ask and listen". Results from this descriptive research showed that 
respondents preferred more participative styles when dealing with grievance.

Teachers in Tanzania specifically in Bukoba Rural has been experiencing grievances, it is not only due to school administrators and workplace conflict but also the issue of getting transfer for spouse to join their partners, on time salary inclement, motivations to work done could contribute to job satisfactionor dissatisfaction of job.. Teachers who possess professional and personal characteristics are humans too; they are not perfect and even not exempted from committing mistakes, there are some circumstances that may turn them into discomfort and dissatisfaction while at work. These conditions are the reasons why despite sincere dedication of teachers, they still commit an action which are against the existing rules and policies of an educational institution (Lucila, 2015).

\section{Living away with spouse,}

Basically, the family is meant to live together, that is father, mother and their children. There is work specialization within the family whereby, everyone has a special duty to perform as family member. Those works also depends on gender, though sometimes they help each other. In relation to that Azim, Haque andChowdhury (2013) in an empirical study of gender, marital status and job satisfaction observed that married employee are more satisfied with jobs than their un married co-workers the reason may be marriage imposes increased responsibilities that may make a steady job more valuable and important. By the time married couple lives together they share a sense of cooperation among them after working hours.Cooking for example, is a women duty together with the female children the same as washing utensils, house cleanliness and fetching water. Whereas for the men they have to think of how to generate more income in terms of doing business in order to fulfil the family needs like having good standard living house, enough food, clothes and enabling children to get better education by giving them all the school requirements as well as sex as basic human needs. Contrary to that Maslow's Hierarchy of Needs(as cited in Saul 2020) where sex is also included as an important need for human being, when it is met, a person can fulfill well his work duties, on the other side if it is not met; it leads to dissatisfaction and hence poor job performance. Biological requirements for human survival according to Maslow include air, food, drink, shelter, clothing, warmthsleep as well assex. If these needs are not satisfied the human body cannot function optimally. Maslow considered physiological needs the most important as all the other needs become secondary until these needs are met.
That means they have to fulfil each ones sexual needs However, when this family need is disturbed it lead to great problems, including, infidelity between spouses, conflicts, misuses of money, increase of street children, and a lot of stresses, consequently, that leads to teachers job dissatisfaction, as a matter of facts, many teachers in Bukoba lives far away from their spouses. They only sometimes meet during the weekend, others only during the holidays. They miss the chance to live together with their spouses and children which results into many problems and stress all that makes them dissatisfied with their job and negatively affect their job performance. Though there is studies on marital status and job satisfaction but there is no studies on Living away with spouse and job satisfaction, the current study aimed onobserving this to be the critical issue to teachers in Bukoba that most of teachers are separated from their husbands/wives due to work while transfer to these teachers to join their partners is been a nightmare story. It is due to this reason that a current researcher need to fill this gap.

\section{Teacher and supervisors' relation}

It is obvious that a good communication among teachers and the supervisor without anime could lead to teachers' job satisfaction.

Jain and Verma (2014) showed that when teachers are satisfied in their jobs, they are more energetic, innovative, and productive. Working collegially could create a web of support that helps teachers with stressful, frustrating, and dissatisfying tasks that hinder job satisfaction Additionally, A mixed methods study by Sudarjat, Abdullah and Sunaryo (2015) which sought to examine the contribution of supervision, leadership and working motivation on teachers' job satisfaction in Indonesia the findings revealed that committed school leadership boosts teachers' job satisfaction. Never the les also Locke (as cited inAzim, Haque\&Chowdhury2013) found that employee satisfaction is increased when the immediate supervisor is understanding and friendly, listen to employees ${ }^{\text {ee }}$ opinions and shows personal interest in them, and offers praise and recognition for good performance. Whenever there is good cooperation among supervisor and subordinates, workers feels a sense of being valued to the extent that they are motivated to perform positively their duties. Additional to that Luthans(as cited inAzim, Haque \& Chowdhury (2013) argued that A good work group ${ }^{\text {ee }}$ serves as a source of support, comfort, advice, and assistance to the individual work and of course, makes the job more enjoyable. The absence of this in the workplace has negative effect on job satisfaction. 
McNeese-Smith (as cited in Ndung'u, 2011) noted that job satisfaction was influenced by the manager. According to him, the character of a manager that influenced job satisfaction include provision of recognition, meeting employee's personal needs, helping or guiding employees, using leadership skills to meet unit needs and supporting the team. Job dissatisfaction is due to managers not giving due recognition and support, not being able to follow through a problem, and not helping but criticizing in a crisis. He further noted besides providing recognition, managers who create a positive climate in tire work environment help employees to be more productive, hr the same study by McNeese-Smith, the use of leadership behaviors was emphasized especially when managers strive to create open communication.. Msuya(2016)in exploring levels of job satisfaction among teachers in public secondary schools showed that work relationship between employees themselves, employees and their supervisors contributed to their job satisfaction and practices. The findings obtained through interviews revealed that teachers were happy working with supportive working maters and involving leaders. Moreover, job satisfaction of employees is positively contributed by whole-hearted relations, group solidarity, and status.

\section{Teacher's accommodation}

Numerous studies have suggested that overall quality of life is dependent on several domains or components of a person's life. These components usually include both housing and work (Andrews \&Withey, 1974; and Campbell, Converse and Rodgers, (as cited in Henderson1987). Also Gupta(2014). Sought that organizations either provide accommodations to its employees who are from different state or country or they provide house rent allowances to its employees. This is done to provide them social security and motivate them to work conveyance: Organizations provide for cab facilities to their employees. Few organizations also provide vehicles and petrol allowances to their employees to motivate them.

The availability of teachers' houses in work place would foster teacher performance due to the fact that could help teachers to be at workplace on time. The inadequacies of teachers' houses lead to teachers to live far from their workplace where they believe that is a safe place to live. Consequently to that most of teachers are forced to rent house and encore transport cost from home place to work station where those costs are from the same low salaries. If there could enough houses to accommodate teachers could be satisfied with the job because the issue of rent and transportation costs could bea nightmare to them hence job satisfaction.Bannel and Makyanuzi study (as cited in
Theresia, 2013) argued that to some extent, differences in job satisfaction levels are due to the different qualification profile of teachers in rural and urban schools.

Increasingly, this difference can be attributed to the much higher living costs and other demands that urban teachers have a deal with on daily basis.

\section{Hostility among teachers}

According toJ.C.Barefoot et al. (as cited in Ermakov et $\underline{\mathrm{al}(2016)}$ in their study conducted in Russia observed hostility as the antagonistic attitude towardspeople including cognitive, affective and behavioral components. Where they viewed affective component includes a number of interconnected emotions, including anger, irritation, offense, indignation, disgust, etc. The cognitive component includes a negative belief concerning a human nature in general (cynicism) and belief in malevolence of other people in relation to the subject (hostile attributions, mistrust)and the behavioral component includes various forms of manifestation of hostility in behavior, often hidden-aggression, negativism, unwillingness to cooperate, communication avoiding etc.

As the swahili saying goes 'jungukuuhalikosiukoko', there are a lot of conflicts in teaching working places.This results from various reasons. One is poor school leadership like favouring the certain individuals than others by head of schools inform of short listing their names in almost every opportunity to get extra income like invigilating or marking national exams, or by not taking equal majors when a certain same misconduct is committed by more than one teacher.

Globally studies has been conducted about hostility and job satisfaction that when workers feels insecure in their workplace due to hostility the result lowers performance hence job dissatisfaction. In a line to that Timothy, Brent\&Remus (2006)in their article of hostility, job attitudes and workplace deviance observed thatinterpersonal injustice may not only induce the experience of negative emotions, such as hostility, but should also decrease employees' satisfaction with their job. Because job satisfaction reflects individuals' evaluations of various aspects of their jobs, and injustice represents a negative aspect of the job, when individuals feel that they have been treated unjustly at work, they will naturally experience lower satisfaction with their job.The results of the meta-analysis on organizational justice by Colquitt et al. (2001) (as cited in Timothy, Brent\& Remus 2006)showed that between-individual differences in interpersonal justice were moderately and positively related to job satisfaction. Employees who are treated fairly during their interactions with their supervisors are 
more likely to view their job and job experiences as more satisfying than those who are treated unfairly.

Whereas one can be harshly punished, the other can be left free repeatedly. Such situation creates enmity groups among teachers which lead to job dissatisfaction because one group will lose the sense of responsibility feeling that they are alienated and disregarded.

On the other hand, work place hostility results from office politics. Some teachers have an attitude of show off. They want to be regarded as much responsible teachers, hard workers at the cost of others by frequently pointing out the mistakes of others than that of their own. That also creates enmity and job dissatisfaction and lowers teachers' performance. Accurate to this Williams (2011) establish that effective handling of conflict can result in effective teamwork and leadership, higher morale, increased productivity, satisfied customers, and satisfied employees. Ineffective conflict management styles in the workplace can lead to low levels of job satisfaction, resulting in high levels of turnover.

Studies on hostility has been done in developed countries basically in health context and other discipline and not in education context as in developing countries there is no such studies concerning hostility.It is due to this reason that a current researcher conducted this on hostilityamong teachers andhow contributes to teachers' job satisfaction specifically in Bukoba rural District as a result of filling this gap.

\section{Health safety to teachers specifically on fighting against corona virus(covid19)}

According to Bender(2020) in key messages and actions for covid 19 prevention control in schools explained that the outbreak of coronavirus disease (COVID-19) has been declared a Public Health Emergency of International Concern (PHEIC) and the virus has now spread to many countries and territories. While a lot is still unknown about the virus that causes COVID-19,we do know that its transmitted through direct contact with respiratory droplets of an infected person (generated through coughing and sneezing) Individuals can also be infected from touching surfaces contaminated with the virus and touching their face (e.g., eyes, nose, mouth). While COVID-19 continues to spread it is important that communities take action to prevent further transmission,reduce the impacts of the outbreak and support control measures.

Taking a school as a heart source of all other discipline and as a centre source of knowledge teachers and students needs to be aware with this new pandemic disease for the safety of all communities in the world, in evident to that Bender, (2020) provide clear and actionable guidance forsafe operations through the prevention, early detection and control of COVID-19 in schools and other educational facilities. The guidance, while specific to countries that have already confirmed the transmission of COVID-19, is still relevant in all other contexts. Education can encourage students to become advocates for disease prevention and control at home, in school, and in their community by talking to others about how to prevent the spread of viruses. Maintaining safe school operations or reopening schools after a closure requires many considerations but, if done well, can promote public health.

As health safety concerns to teachers, the invasion of corona virus has been referred to be the next strongest problem to teachers' job satisfaction in Bukoba Rural District (current researcher 2020).

That is because the workplace conditions are not friendly due to overcrowding of students in classes, inadequate of water andlack of enough funds for buying sanitizers and building extra classes in order to avoid overcrowded classes.

Furthermore, most of teachers specifically those who are about to retire are much not comfortable with the situation of coronadisaster since they already have health problem due to their age. Evident to that, $\mathrm{WHO}(2020)$, viewed thatOlder people, and those with underlying medical problems like cardiovascular disease, diabetes, chronic respiratory disease, and cancer are more likely to develop serious illness if they are to be infected by corona viruses.

Never the lesCDC(2020) suggests that, whether you are going into work or working from home, the COVID-19 pandemic has probably changed the way you work. Fear and anxiety about this new disease and otherstrong emotions can be overwhelming, and workplace stress can lead to burnout. How you cope with these emotions and stress can affect your well-being, the well-being of the people you care about, your workplace, and your community. Therefore few studies on corona virus has been done worldwidethat is why the current researcher was interested to investigate on covid 19 how it contribute to teachers job satisfaction in Bukoba.

\section{Strategies which can be adopted to improve workplace standards}

\section{Living away from spouse,}

Government should consider spouses by providing them transfer so that they can be together in a way that they perform their family matters. As it shows in public civil servant standing order of Tanzania of 2009 in G.12 states that married public servant attending courses outside the country of not less than two academic years' of duration, government may be granted to assist a public servant's spouse in order to reduce the danger of matrimonial 
disruption liable to be caused by prolonged separation. Therefore for teachers who are married and they are teaching in different regions with their partners they should be considered be provided transfers without any difficulties so that they can join their spouse with this a teacher will be more likely to be satisfied with their jobs.

\section{Teacher supervisor's relation}

Kumar (2011) argues that the source of job satisfaction is not only the job; it is also derived from supervision style. Effective supervision emanating from school administration has the ability to create a sense of being valued among teachers which eventually creases the level of job satisfaction among teacher. Additional to that Olsenand Huang(2018) suggested that Teacher cooperation and principal support within the school are two influential factors that directly relate to job satisfaction. After controlling for teacher- and school-level characteristics, principal support and teacher cooperation were statistically significant predictors of job satisfaction for all teachers where the findings emphasize the need to maintainprofessional communities where teachers can interact and collaborate with the support of their school leaders.

In research byMwamwenda (1995) cited in Nyagaya (2015) on the factors influencing job satisfaction among secondary schools white teachers in South Africa, the variables that emerged from these studies were aspects pertaining to working conditions, interpersonal relations with managers, colleagues and learners, professional development, management styles and community involvement. Factors affecting job satisfaction among white teachers covered a broad spectrum and including intrinsic as well as extrinsic factors.

\section{Teacher's accommodation}

The findings in a study by Obineli (2013) strengthened that inspired workplace will inspire teachers to work. The findings further reveal that quality and style of buildings and offices with sufficient ventilation, lighting and cleanliness important in creating an effective school environment. Likewise, a study by Hill (2010) reported that teachers spend so much time in their work environment each week and therefore it is important for schools to try to optimize their working conditions like providing spacious work areas rather than cramped ones because adequate lighting and comfortable work stations contribute to favorable work conditions.

In standing order under section L. 34 shows that public servant whose terms and conditions allow them free housing allowances shall be paid. It should be applied also to teachers as they are part of public servant which could reduce the burden of paying rent from their low and unincremental salaries they get or if there could be a chance for government to build teachers' houses in each schools they teach.

\section{Grievances andHostility among teachers}

A study byNganzi (2013) reported that teacher's job satisfaction is an unavoidable phenomenon in the school environment. Nganzi added that teachers need to be motivated and reinforced in their career if they are to execute a quality job in schools. Falling short of deadlines results in conflict between employees and supervisors and raises stress level of the workplace. In most cases, this environment is caused by ineffective management and poor planning. Similarly, a study by Kabango (2013) reported that schools need to have a mechanism to evaluate teachers' performance and provide salary increases for top performers. Additionally, a study by Okonkwo and Obineli (2011) reported that if secondary school teachers are well paid, they can still go an extra mile to ensure that they have a stimulating working environment. Thus, opportunities to earn special incentives, such as bonuses, extra paid time off or vacations, also bring excitement and higher job satisfaction to the workplace.

Health safety to teachers specifically on fighting against corona virus (covid19)

Literature presupposes that availability facilities and fund to fight against corona virus of could improve the school working condition which in turn may trigger teacher job satisfaction. For example, Beteille (2020) came up with three principles which was to support teacher resilience to ensure teacher effectiveness, support teachers instructionally to ensure teacher effectiveness and support teachers technologically to ensure teacher effectiveness to strengthen teachers effectiveness during and immediate aftermath of the pandemic as well as opportunities for long run improvement

\subsection{Research Gap}

Kumar (2011) asserts that a study area describes the organization in which one will conduct the study. This study was conducted in Bukoba District because many studies on the influence of schools workplace condition on teachers' job satisfaction have been conducted in cities like SHONJE, (2016) Influence of Working Conditions on Teachers Job Satisfaction in kisaraweDistrict, Kyara,(2015)The Effect of Primary School Teachers' Job Satisfaction on their Work Performance in Kinondoni District and Msuya(2016) in Exploring levels of job satisfaction among teachers in public secondary schools in Mwanga district not yet in this District. Another reason for selecting the area of study is because the researcher is a teacher and she is working in Bukoba District since 2012. Thus, the researcher was familiar with the area where 
Public Secondary Schools in Bukoba Rural District in Kagera Region, Tanzania

might be easier to gather the contribution of workplace standards on teachers' job satisfaction, and strategies which can be adopted to improve workplace standard so as to enhance sustainable teachers' job satisfaction environment and come up with reliable findings that can be turned into workable and sustainable solutions and less than that there is no study has been conducted in this district of Bukoba concerning covid 19 incident as contributor to teachers job satisfaction.

\section{RESEARCH METHODOLOGY}

The current study employed mixed research approach. This is due to building on knowledge and strength of the data collected on both quantitative and qualitative approaches to understand the phenomenon in details. This study employed convergent parallel research design. Which helped to limit some danger which would occur if other designs basically those which require the research to go twice to the field. The target population of this study comprised of all teachers, heads of the schools, Ward Education Officers and District Education Officer in Bukoba District. Which has a total of 40 secondary schools, where 30 schools are public and 10 are private schools with a total population of 461 teachers, 40 Heads of schools, 29 Ward Education Officers and one 1 District Education Officer (District Officer, 2019). Thus, the target population for this study comprised of 531 people. The sample for this study was drawn from the target population using Yamane's formula.

$\mathrm{n}_{\mathrm{s}}=\frac{\mathrm{N}}{1+\mathrm{N}(\mathrm{e})^{2}}$

Whereby

$\mathrm{n}_{\mathrm{s}}=$ Sample size

$\mathrm{N}=$ Total population

$\mathrm{e}=$ Confident level

Given

$\mathrm{N}=531$

$\mathrm{e}=0.1$

$\mathrm{n}_{\mathrm{s}}=$ ?

$\mathrm{n}_{\mathrm{s}}=\frac{531}{1+531(0.1)^{2}}$

$\mathrm{n}_{\mathrm{s}}=\frac{531}{\mathbf{5 3 2 ( 0 . 0 1 )}}$

$\mathrm{n}_{\mathrm{s}}=\frac{531}{5.32}$

$\mathrm{n}_{\mathrm{s}}=99.8130$ which is approximately 100 .

Therefore, the sample size of this study consisted of one hundred (100) respondents.

Table 3.1: Sample Size

\begin{tabular}{|c|c|c|c|c|}
\hline $\begin{array}{l}\text { Categories } \\
\text { Respondents }\end{array}$ & of & Population & Sample Size & Sampling Procedure \\
\hline DEO & & 1 & 1 & Purposive \\
\hline WEO & & 29 & 3 & Purposive \\
\hline Heads of schools & & 40 & 4 & Purposive \\
\hline Teachers & & 461 & 92 & Simple random \\
\hline Total & & 531 & 100 & \\
\hline
\end{tabular}

Source: Researcher (2019)

\section{Sampling Techniques}

According to Oso and Onen (2016) Kumar, 2011). Sampling is a description of the strategies which the researcher will use to select representative respondents from the target/accessible population. The researcher used simple random sampling to select 92 teachers The researcher identified the population from which the sample was drawn and thereafter randomly selected the needed sample.In carrying out simple random sampling, the researcher labeled pieces of papers. Some pieces of papers were labeled "YES" while others "NO". Those who picked pieces of papers labeled YES participated in the study while those with NO did not participate. In this way, 23 teachers were sampled from each of the four sampled schools making a total of 92 teachers. Additionally, purposive sampling technique was used to select participants for this study.). In this method, the researcher purposively selected 4 heads of schools, 3 Ward Education Officer and 1 District Education Officer. The current study employed unstructured interview so as to solicit in-depth information about workplace condition and its influence on teachers' job satisfaction. Interview was conducted to 1 
DEO, 3 WEOs and 4 heads of schools Also researcher used structured Questionnaires with both open and close ended questions to teachers due to their large in numbers. In order to ensure face and content validity, the questionnaire and interview guide were given to the supervisor and panelists of St. August University of Tanzania to check and see if the items could help to obtain relevant information to answer the research questions. The given insights helped the researcher to restructure and modify the items in the research instruments. The data obtained from a pilot study were coded, entered into SPSS and analyzed to give an internal reliability or consistency through Cronbach's Alpha Correlation Coefficient. The researcher used a field note book to record qualitative data during interview. Quantitative data were directly recorded by the respondents in the spaces provided in the questionnaires. Data analysis of this study included both qualitative and quantitative data that were collected from the field. Quantitative data was analyzed through descriptive statistics basically frequencies and percentages by using a Statistical Package for Social Sciences (SPSS) version 20. Thematic analysis was employed in the analysis of qualitative data collected through interview. The qualitative data were transcribed, organized, identified and categorized into both major and recurring themes which were then presented inform words or descriptions.In conducting this study, ethical issues were considered like permission from the authorities, confidentiality, openness, anonymity and acknowledgment. The names of the respondents were kept confidential, there was no particulars requiring the respondent's name in the questionnaire. Researcher also assured the respondents that the information which they had to provide would be kept confidential and that there would be no any side effects to them regarding their participation in providing the required information.

\section{PRESENTATION AND DISCUSSION OF THE FINDINGS}

\section{Teachers perceptions about work place standards}

The results for this objective are summarized and presented in table 4.5 below. Apart from that, the respondents were also asked on how they view their workplace condition.

Table 4.5: School Working Environment on Teachers' Job Satisfaction

\begin{tabular}{|c|c|c|c|c|c|c|}
\hline \multirow[t]{2}{*}{ Items } & \multicolumn{2}{|c|}{$\begin{array}{l}\text { Highly } \\
\text { satisfied }\end{array}$} & \multicolumn{2}{|c|}{$\begin{array}{l}\text { Average } \\
\text { Satisfied }\end{array}$} & \multicolumn{2}{|c|}{$\begin{array}{l}\text { Low } \\
\text { Satisfied }\end{array}$} \\
\hline & $\mathbf{f}$ & $\%$ & f & $\%$ & f & $\%$ \\
\hline $\begin{array}{l}\text { School Working condition is supportive for teachers to fight } \\
\text { against corona virus where I teach }\end{array}$ & 8 & 8.3 & 63 & 65.6 & 25 & 26.0 \\
\hline There are teachers' houses where I teach. & 10 & 10.4 & 10 & 10.4 & 76 & 79.2 \\
\hline $\begin{array}{l}\text { There is a good way of settling grievances and hostility in my } \\
\text { school where I teach }\end{array}$ & 11 & 11.5 & 60 & 62.5 & 25 & 26.0 \\
\hline $\begin{array}{l}\text { There is good relationship between school supervisor and teachers } \\
\text { in school I teach. }\end{array}$ & 15 & 15.6 & 60 & 62.5 & 21 & 21.9 \\
\hline $\begin{array}{l}\text { Teachers who are married they are living together with their } \\
\text { husband/wife in school where I teach or within district. }\end{array}$ & & - & 27 & 28.1 & 69 & 71.9 \\
\hline
\end{tabular}

Source: Field Data (2020)

Table 4.5 shows that that 65.6 percent of the teachers reported that they were averagely satisfied with the environment while 26.0 percent were lowly satisfied and 8.3 percent were high satisfied. The finding indicates that the school workplace is not supportive enough with facilities that are for war against corona virus. For that reason, the overall quality of the condition in which teachers live and work is a powerful influence factor of job satisfaction and motivation if the condition is poor teachers reduce work morale. In relation to that, Adegun (1999) showed that a number of factors hamper teachers' job performance or productivity such as the society's high expectations and output in the school systems. These factors have been listed as constituting the teachers' work environment. Similarly, 79.2 percent of the teachers reported that they were lowly satisfied with school housing; while 10.4 percent each indicated that they were averagely and highly satisfied with school housing services. From the findings, there is no support for teachers' housing in their schools. It seems that, there is 
inadequate number of teacher' house compared to the availability of teacher in school areas. This is supported by MOEC (2003), observed that in school environment lack teaching and learning materials, low salaries, inadequate training and development programs, social status accorded to them within the communities, inadequate teachers housing, workload being heavy and work environment and overcrowded classes compared to the ratio of teacher. Therefore, the teachers' working conditions if are well provided, they will improve teachers job satisfaction. Apart from that, 62.5 percent of the teachers reveal that the school workplace are not conducive enough due to poor methods used in settling teachers grievances and hostility while 26.0 percent were lowly satisfied and while 11.5 percent were highly satisfied. According to Rahim, Magner and Shapiro, 2000) shows that there should be appropriate styles used to resolve workers' grievance that will improve the efficiency and effectiveness of grievance procedure

Therefore, the workplace condition for teachers is not well equipped to support the teaching profession. Additionally, the results in table 4.5 further reveal that 62.5 percent of the teachers revealed that they were averagely satisfied with the relationship between teachers and their school supervisor, while 21.9 percent were lowly satisfied with the relationship of teacher and supervisor in school workplace and 15.6 percent of them were highly satisfied with the good relationship of teachers and their school supervisor. Msuya (2016) in exploring levels of job satisfaction among teachers in public secondary schools showed that work relationship between employees themselves, employees and their supervisors contributed to their job satisfaction and practices.

The results also indicate that 71.9 percent of the teachers indicated that they were lowly satisfied with living away from their spouses, while 28.1percent were averagely satisfied with the situation. In light of these results, the married teachers to be more stressed with their marriages due to living far from their spouse. Thus, majority of the teachers doubt their husband/wives because of distances where mostly they met during long holidays only. In this situation, Maslow's Hierarchy of Needs (as cited in Saul 2020) where sex is also included as an important need for human being, when it is met, a person can fulfill well his work duties, on the other side if it is not met; it leads to dissatisfaction and hence poor job performance. It has been noted that workplace condition such as absence of grievances and hostility among teachers, presence of teachers' houses, good relationship among teachers and school supervisor, married teachers to live with their spouses and teacher's health safety influences teachers' satisfaction in most secondary of Bukoba District.
Therefore, the workplace condition is a huge contributor to the teaching staff as it affects teacher's commitment.

Overall Rate of teachers' perception on school Workplace Condition on Job Satisfaction

. The findings are as summarized in Table 4.6.Table 4.6: Rate of Working Environment

\begin{tabular}{lll}
\hline Items & Frequency & Percent \\
\hline Motivating & 7 & 7.3 \\
Fairly motivating & 58 & 60.4 \\
De-motivating & 31 & 32.3 \\
\hline
\end{tabular}

Source: Field Data (2020)

The findings show that 60.4 percent of teachers and 100 percent of all heads of schools rated that the working conditions as fairly motivating while 32.3 percent of teachers rated the working conditions as de-motivating and the remaining 7.3 percent of them rated the working condition as motivating. The results suggested that poor working conditions in secondary schools is a problem to most teachers working in Bukoba District. Nearly over half of the respondents rated their own working conditions as 'fairly motivating' or 'de-motivating compared to only 7.3 percent teachers who rated their working conditions as motivating.

The qualitative results from interview with interviewees were in agreement with the findings above. During the interview with the interviewees they recognized that teachers were working in poor environment and most of schools in the district were scattered and found in remote areas.

Interviewee 1 acknowledged,

Although most secondary schools
in our district have tried to
improve on school infrastructure,
most teachers are not happy with
these schools and would change
their teaching environment if a
chance occurred. For this reason
they find the school working
conditions de-motivated to
continue teaching, something that
depleted their moral (Interviewee
$1,12^{\text {th }}$ March, 2020).

Another interviewee when asked replied,

Majority of secondary schools teachers in Bukoba District had negative attitude with the working condition. The school condition don't attract and retain 
Public Secondary Schools in Bukoba Rural District in Kagera Region, Tanzania

teachers as the schools have never satisfied with workplace they work due to shortage of necessary psychological needs and facilities like teacher's housing, poor cooperation among teachers and their supervisor, living away with spouse (Interviewee 2, 13 ${ }^{\text {th }}$ March, 2020).

Moreover, the other interviewee had this to add,

Teachers are de-motivated due to the fact that, apart from working in a poor workplace conditions, still they are separated from their spouses and families, grievances and hostility among teachers leading to high levels of discontentment. Also, teachers in Bukoba District lacked support from parents and local leaders, something that makes them to work in difficult condition (Interviewee 3，14 ${ }^{\text {th }}$ March, 2020).

Additionally, interviewee 4 he was asked about the working conditions of teachers in their schools and he said that teachers are working in not so poor and de-motivating conditions. However, the working condition in which teachers are teaching is fairly motivating. In his responses, he noted that,

Working environment is not a
major concern for most teachers.
However, when teachers are
unable to meet their expectations
where they work hence it leads to
de-motivation, making them to
hate the job and ready to leave
the teaching profession at any
opportune time (Interviewee 4 ,
$25^{\text {th }}$ March, 2020).

However, he noted that teachers were working in complicated condition characterized with the shortage of necessary facilities such as lack of houses, enough funding for buying facilities that are used to fight against covid 19 as heath safety is concern to teachers, long distance to schools workplace.

\section{The contribution of workplace standards on Teachers' Job Satisfaction}

This section presents the findings for the second research objective which was sought to determine the contribution of workplace standards on teachers' job satisfaction. Thus, the respondents were asked to assign their level of agreement as measure of 1-agree, 2-not being sure and 3disagree. The findings are presented in table 4.8.

Table 4.8: Contribution of school workplace standards on Job Satisfaction

\begin{tabular}{|c|c|c|c|c|c|c|}
\hline \multirow{2}{*}{$\begin{array}{l}\text { Items } \\
\text { Are there grievance and hostility among teachers }\end{array}$} & \multicolumn{2}{|c|}{ Agree } & \multicolumn{2}{|c|}{ Not Sure } & \multicolumn{2}{|c|}{ Disagree } \\
\hline & 71 & 74.0 & 12 & 12.5 & 13 & 13.5 \\
\hline Are there teachers living away from spouse & 76 & 79.2 & 14 & 14.6 & 6 & 6.3 \\
\hline Teacher's accommodation & 66 & 68.8 & 14 & 14.6 & 16 & 16.7 \\
\hline Employee and supervisor's relation & 74 & 77.1 & 14 & 14.6 & 8 & 8.3 \\
\hline $\begin{array}{l}\text { Teachers health safety in terms of availability of facilities used } \\
\text { against covid } 19\end{array}$ & 78 & 81.3 & 10 & 10.4 & 8 & 8.3 \\
\hline
\end{tabular}

Source: Field Data (2020)

The findings in table 4.8 indicate that 74.0 percent of all the respondents as shown in table 4.8 agreed that the grievance and hostility among teachers are contributing conditions on low job satisfaction, while 13.5 percent disagreed and 12.5 percent were not quite sure. Likewise a study by Chonjo (1994) argued that teachers spend their free or spare time preparing lessons and planning what to teach, much of time is spent on planning how to survive. Implication to that, the low level of incomes forces teachers to live in poor accommodation, eat poorly, and dress shabbily to an extent that people look down on the teaching profession for that matter, the government should look on it in order to improve quality of teaching professions that teachers grievances are solved.

Likewise, the results indicate that 79.2 percent of all the teachers as shown in Table 4.8 agreed that the teachers living away from spouse leads to teacher's indiscipline 
cases being promoted in schools, and 14.6 percent were not sure, while 6.3 percent disagreed. In light of these findings, job dissatisfaction lead to increases of indiscipline cases in the school. It seems that majority of teachers go against professionalism most of them did act unethical. Contrary to that, Davidson (2004) revealed that teacher's workload has been high due to the shortage of teachers, especially in rural areas. As such, teachers are demotivated by the situation leading to a decrease in their profession efficiency.

Besides, the findings also show that 68.8 percent of the teachers as shown in table 4.8 agreed that lack teachers accommodation affects job satisfaction, while 16.7 percent of them disagreed, and14.6 percent of the respondents were not sure. In school context conflict it occurred for the reasons such as lack of motivation for teachers, lack of increments and compensation. The study by Babyegeya (2002) illustrated that the subject of motivation and working conditions of teachers in many rural schools across the school context have continued to gain wide spread criticisms because of the obvious difficulties rural schools face in attracting and retaining qualified teachers. Table 4.8 further shows that teachers are being tortured psychologically and mentally with the poor relation between teachers and supervisor as noted by 77.1percent of the teachers who agreed while14.6 percent were not sure, and 8.3 percent of them disagreed.
The findings also show that 81.3 percent of the teachers agreed that teachers' working dissatisfaction was an influential factor leads to high low teaching performance due to poor health safety at school fearing the danger of covd 19, 10.4 percent were not sure while 8.3 percent disagreed. This agrees with Mulkeen (2005) lack of staff houses, shortage of water, and lack of social services such as medical and communication services, especially in rural areas affect teachers' professional efficiencies. Therefore, teachers will not attain the education goals if their needs are not met. Similarly, issue of absenteeism among teachers was associated with poor workplace conditions, because the schools absence of social services like health care, lacked sufficient houses for teachers to stay with associated with low salaries for teachers which compelled them to use school time to make money to supplement their needs (Shonje, 2016).

\section{Strategies for Effective working condition and Teachers' Job Satisfaction}

This section presents and discusses the findings for the third research objective which determined the strategies for improving working environment hence fostering teachers' job satisfaction in public secondary schools. The results are presented in table 4.9 below.

Table 4.9: Strategies for Improving Working Environment for Effective Teachers' Job Satisfaction

\begin{tabular}{lll}
\hline Items & Frequency & Percent \\
\hline Settling grievances and hostility among teachers where I teach & 21 & 21.9 \\
Teachers' housing are provided & 33 & 34.4 \\
Teachers living with their wife/husband & 17 & 17.7 \\
Provision of good relationship among teachers and supervisor & 12 & 12.5 \\
Knowledge provision to teachers' health safety on corona virus & 13 & 13.5 \\
\hline
\end{tabular}

Source: Field Data (2020)

Table 4.9 shows that 21.9 percent of the respondents suggested that the schools should impose good ways of settling down grievances and hostility in school for improvement of quality school workplace condition. The majority of the respondents views that the absence of grievances and hostility among teachers lead to teacher performance hence teachers' job satisfaction. Teachers are able to play their role when they are satisfied with their teaching condition and it is easier for them to impact knowledge to students. This concurs with Obineli (2013), who strengthened that inspired workplace will result in inspired workers and draws attention to the importance of work performance. Moreover, the findings in table 4.6 shows that 34.4 percent of the respondents were of the view that the schools should improve quality of teachers' house and offices. In order to increase effectiveness, productivity and commitment, teachers must be satisfied with their housing facilities with access to water and electricity services. This satisfaction comes when teachers accommodated in good school houses. It should be noted that teachers housing does not only mean the number of houses available in school environment, but also entails that the school should be able to pay for teachers housing allowances.

This finding concur with Mulkeen (2005), who recommended that teachers' job satisfaction require 
adequate classroom equipment with facilities like furniture's, books and conducive working environment.

Additionally, table 4.6 also shows 17.7 percent of teachers suggested that the school leaders should be able to find a way for teachers to live with their spouse that makes families not to apart from each other. The majority of teachers were of the view that despite of the good working condition, the fact of being away with wife/husband leads to teachers dissatisfaction and spent much time seeking for transfers to join their spouses. In addressing the importance of this position,Azim, Haque\&Chowdhury (2013) in an empirical study of gender, marital status and job satisfaction observed that married employee are more satisfied with jobs than their un married co-workers the reason may be marriage imposes increased responsibilities that may make a steady job more valuable and important.

Similarly, in Table 4.6, 12.5 percent of teachers were of the view that Provision of good relationship among teachers and supervisor is very important for teachers in order to create a conducive condition for them to teach effectively.

This is supported by Sudarjat, Abdullah and Sunaryo (2015) which sought to examine the contribution of supervision, leadership and working motivation on teachers' job satisfaction in Indonesia the findings revealed that committed school leadership boosts teachers' job satisfaction.

This agrees with interviewee 3 , who was of said that,

Many teachers lose their morale
with their jobs due to poor
relationship with school
supervisor. This situation affects
teachers work performance which
leads to job dissatisfaction
(Interviewee 3, March, 2020).

Similarly, interviewee 6 during the interview session had this to say: "Provision of good relationship among teachers and supervisor is among the significant rewards in school that gives hope and motivation to a maximum number of teachers".

Interviewee 7 maintained that "Provision of good relationship among teachers and supervisor, provide greater personal comfort for teachers and boost their morale".

Also, interviewee 8 added that,

The provision of good relationship among teachers and supervisor is a foremost means of encouraging teachers to work hard. Therefore, it will be difficult for teachers to be satisfied with their workplace condition as long as there is no cooperation and good terms between teachers and their supervisor (Interviewee 8, March, 2020).

It is generally observed that, often little or nothing is that teacher's job satisfaction is unavoidable phenomenon in a school environment. Teachers need to be motivated and reinforced in their career if they are to execute quality jobs in schools. Dealing with a workload that is far too heavy and deadlines that are impossible to reach can cause job satisfaction to erode for even the most dedicated employee. Falling short of deadlines results in conflict between employees and supervisors and raises the stress level of the workplace (Nganzi, 2013).

\section{CONCLUSIONS AND RECOMMENDATIONS}

From the findings of the study, the workplace is not well motivated and draws attention to the teachers by undermining their working performance. The workplace embraces working as lack necessary facilities like availability and suitable health care as covid 19 is concern, suitable methods of grievances and hostility settling style among Teachers, provision of transfers for teachers who a living away with their spouses so that they can live together as the family. From the study, teachers were not satisfied with their workplace as it affects teacher performance. The findings also maintain that teachers' workplace in terms of the teaching environment remains a serious problem as it characterized with grievances and hostility among teachers, inadequate teachers house, living away from spouse, health safety as corona endanger teachers life, teachers' supervisor relations where are often either not sufficient nor adequate to enhance effective service delivery.

Workplace condition is an important issue that can affect the satisfaction of teachers in schools. Some teachers experience stagnation lowering their teaching performance. When this occurs, they are demoralized, frustrated and dissatisfied with their workplace conditions. This dissatisfaction can also be manifested in low commitment to work, low teaching morale and creativity.

Hence, to improve the working condition, strategies would be effective contributions of teachers' workplace condition towards improving the level of job satisfactions. workplace conditions such as, availability and suitable health care as covid 19 is concern, suitable methods of grievances and hostility settling style among Teachers, provision of 
transfers for teachers who a living away with their spouses for them to live together as the family.

The current study investigated the influence of school workplace condition on teachers' job satisfaction in public secondary schools in Bukoba District. For that reason, the researcher suggested that a similar study should be carried out in private schools so as to determine whether workplace conditions influence teachers' job satisfaction. Apart from that, this study was limited to questionnaire and interview as methods of data collection of which more factual information on the physical school condition may have obtained. Thus, it is recommended a similar study to be conducted with high level of triangulation in which observation and focus group discussion should be employed as methods of data collection. Additionally, although this study managed to come up with relevant findings, it was limited to 100 participants who were sampled from 4 public secondary schools in Bukoba District only; therefore, a similar study could be done in a large geographical area involving more participants from which more valid and reliable findings can be obtained.

\section{REFERENCES}

[1] Adegun, A. O. (1999). Socio-economic characteristics and teachers' effectiveness in Ekiti State, Nigeria. Benin City: African Journal of Education, 4(2), 180-181.

[2] Allodi, M. W., \&Fischbein, S. (2012). Teachers' perceptions of their work environment in Swedish junior high schools.Research in Comparative and International Education, 7(3), 376-393

[3] Alyaha, D.O., Mbogo, R.W. (2017). Impact of Working Conditions on Teacher"es Job Satisfaction and Performance in the Private Primary Schools in Yei Town, South Sudan.IRA International Journal of Education and Multidisciplinary Studies, 8(1), 122-129.

[4] Anna, T., Eva, M,.\& Stefan, J.(2020).Teacher job satisfaction: the importance of school working conditions and teacher characteristics, Educational Review, DOI: $10.1080 / 00131911.2019 .1705247$

[5] Ayadura, D(1996) Industrial Relations in Malaysia: Law and Practice $2^{\text {nd }}$ Edition. Kuala Lampur: Malayan Law Journal.

[6] Babyegeya, E. B. (2002). Educational Planning and Administration.Dares Salaam: Open University of Tanzania.

[7] Bean, R.(1994) Comparative Industrial Relations: An Introduction To Cross-National Perspectives. $2^{\text {nd }}$ Edition. London: Routiedge.

[8] Chaykowski, R.P. \&Slotsve, G.A (1992). A Simultaneous Analysis Of Grievance Activity And Outcome Decisions. Industrial \& Labour Relations Review, 45(1), 724-738.

[9] Davidson, E. (2005). Understanding and improving quality in Tanzanian primary schooling. School of development studies, University of East Anglia. Unpublished PhD Thesis.
[10] Gomez-Mejia L.R; Balkin, D.B and Cardy, L.R (2005) "Managing Human Resources $6^{\mathrm{TH}}$ Edition". Printice Hall, one Lake Street, Upper saddle river, New jersey.

[11] Gupta, M. ( 2014). Employees' Satisfaction Towards Monetary Compensation Practices. Global Journal of Finance and Management. Volume 6, Number 8(2014), pp. 757-764.

[12] Henderson, C. G. (1987). "The influence of housing satisfaction on job satisfaction, job performance and overall quality of life "(1987).Retrospective Theses and Dissertations. 8653.

[13] Ivankova, M.V. (2015). Mixed Methods Application in Action Research: from methods to community Action. USA: SAGE Publication Inc. retrievedtrom https//www.google.com18th 2020

[14] Jabareen, Y. (2009). Building a conceptual framework: philosophy, definitions, and procedure. International journal of qualitative methods, 8(4), 49-62.

[15] Lucila, M. (2015). Level of Awareness of TNHS Administrators and Faculty on the DepEd Grievance Policies and Procedures: Basis for the Formulation of TNHS Institutional Grievance Policies and Procedures

[16] McLeod, S. A. (2020, March 20). Maslow's hierarchy of needs.Simply Psychology. https://www.simplypsychology.org/maslow.html

[17] MOEC (2003).Joint Review of Primary Education Development Plan. Dar esSalaam: United Republic of Tanzania.

[18] Mulkeen, A., \& Chen, D. (Eds.). (2008). Teachers for rural schools: experiences in Lesotho, Malawi, Mozambique, Tanzania, and Uganda.The World Bank.

[19] National Science Board.(2008). Elementary and secondary education. Science and engineering indicators, Arlington, Virginia.

[20] Ndung'u, M. N. (2011). The Influence of Grievance Handling on Employee Job Satisfaction in Private Secondary Schools in Thika West District

[21] Nganzi, C. (2013). Factors influencing secondary school teachers' job satisfaction levels in Lang'ata District, Nairobi, Kenya. International Journal of Community and Cooperative Studies, 1(2): 12-26.

[22] Ntagahali, G. S. (2016). The Influence of Working condition on Teachers Job Satisfaction. The case of Kisarawe District. Open university. Tanzania.

[23] Obineli, A. S. (2013). Teachers' perception of the factors affecting job satisfaction I Ekwusigo Local Government of Anambra State, Nigeria. African Research Review, 7(4), 225-237.

[24] Oso,W.Y., and Onen, D. (2016). Writing research proposal and report; A handbook for Beginning Researchers. Revised Edition. Jomo Kenyatta foundation.

[25] Shibitali, C.K, (2012). Contemporary historical Events: Che Guevara Investment, Dar essalaam Tanzania.

[26] Shukla, A.K. (2007). Woman Chief Ministries in Contemporary India. NEW DELHIU: APH Publishing Cooperation. Retrieved from https://www.google.com/20TH 2020 
Public Secondary Schools in Bukoba Rural District in Kagera Region, Tanzania

[27] Simon, N. and Johnson, S. (2015). Teacher turnover in highpoverty schools: What we know and can do. Teachers College Record, 117(3), pp.1-36.

[28] Sims, S. (2017). TALIS 2013: Working conditions, teacher job satisfaction and retention (Department for Education Statistical Working Paper). London: Department of Education.

[29] URT, (2009).Standing orders for the public service : $3^{\text {th }}$ Edition. United Republic of Tanzania.

[30] William, O.M. (2016). Exploring Levels of Job satisfaction among Teachers in Public secondary schools in Tanzania. International Journal of Educational Administration and Policy Studies Olsen, A. A., \& Huang, F. L. (2018). Teacher job satisfaction by principal support and teacher cooperation: Results from the Schools and Staffing Survey. Education Policy Analysis Archives, 27 (11). http://dx.doi.org/10.14507/epaa.27.4174 